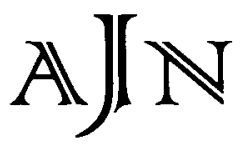

\title{
Control of hyperphosphatemia in regular hemodialsis (HDx) patients by calcium acetate (CA) versus calcium carbonate (CC). A Double blind crossover prospective study
}

\author{
U AA Sharaf El Din, M Mansour, M ElHamamsy, EHG El Ghonaimy, and LA Mansour*
}

Departments of Internal Medicine and Clinical Chemistry*. Faculty of Medicine. Cairo University.

\begin{abstract}
This study included fourty chronic renal failure patients aged $37-83$ years (mean $51.3 \pm 7$ ) on thrice weckly HDx for 4 - 144 month $(K 1 / V>1.2)$.

Acclatc dialysate with Calcium concentration of 3 $\mathrm{mEq} / \mathrm{L}$ was used. All phosphate binders were discontinued for one month.

Palients were divided in two groups. Group I (20) cases) received CA, while group II (20) cases) received $\mathrm{CC}$ in equimolar dose $(10 \mathrm{~m}$. mol. of either t.i.d.) for one month. Crossover of trealmem was done for another month while keeping patient on the same dict.

Serum levels of tolal calcium (Ca), ionised Ca (iCa). phosphorus (P), alkaline phosphates (AP), urca (U). creatinine $(\mathrm{Cr}), \mathrm{ALT}, \mathrm{AST}$, total proteins (TP) and albumin (Alb) were estimated before, and at the end ol each month of CA and CC treatment.

scrum $C a$ and $i C a$ were significanlly lower in group I alier $C A$ compared 10 values after $C C(P<0 .(0)$ ). Similar results in Ca levels were observed in group II $(P<0.05)$.

In group II only serum $P$ was significantly lower afier $C$ A compared to its values after $C C(P<0.05)$.

There was no significant difference in $A P, U, C r$, ALT, AST, TP and Alb before, and at the end of each month of $\mathrm{CA}$ and $\mathrm{CC}$ treatment ( $P>0.05$ in all). We excluded $12.5 \%$ of cases due to $\mathrm{CA}$ intolerance white non of cases had similar intolerance to $\mathrm{CC}$.
\end{abstract}

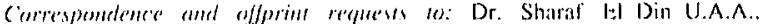
Departments of Intermal Medicine, faculty of Medicine. Camro Univenity. ligypl.

\section{Conclusion}

1) $\mathrm{CA}$ is not very superior to $\mathrm{CC}$ in control of hyperphosphataemia.

2) CA can be safely increased without the risk of hypercalcemia.

3) Active Vitamin D and high dialysate Ca can be used to suppress parathyroid activity more safely with CA than with CC.

4) Tolcrability to $\mathrm{CC}$ is superior.

\section{Introduction}

llyperphosphatemia plays a major role in renal ostcodystrophy 19]. The management of hyperphosphatemia is rather difficult as poor phosphate dict may interfere with adequate nutrition of chronic renal failure patients.

Morcover, phosphate binders have many drawbacks |16|. The first phosphate binder used was aluminium hydroxide. Constipation is common and more seriously aluminium intoxication in uremic paticnts recciving this compound for a long time $\{26,23\}$. Calcium carbonate was thus introduced to replace aluminium compounds. It causes hear burn, constipation beside the risk of hypercalcemia. This last side effect may deprive many urcmic patients from using active vitamin $D$. the most potent suppressor of the parathyroid gland $|12,22|$. 
More recently calcium acetate was introduced as a phosphate binder [22].

\section{Aim of work}

This prospective double blind crossover study was designed to compare equivalent amounts of calcium acetate and calcium carbonate (in terms of elemental calcium) in the control of hyperphosphatemia in chronic renal failure patients maintained on regular hemodialysis.

\section{Materials and methods}

Fourty hemodialysis patients were studied. Their age ranged between 37 and 83 years (mean $\pm S D=51.3 \pm 7$ ). They were 31 male and 9 female on thrice weekly hemodialysis for $4-144$ months using the same type of dialyzer membrane, namely cuprophane, and the time of dialysis session was individualized to keep $\mathrm{Kt}$ / $V>1.2$. All patients had residual creatinine clearance of less than $5 \mathrm{ml} /$ minute. A standard acetate dialysate with a calcium concentration of $3 \mathrm{mEq} / \mathrm{L}$ was used. All patients were clinically stable and were kept on oral calcium carbonate in a dose of $10 \mathrm{~m}$.Mol threc times/day and $0.25 \mathrm{ug}$ of $1-\alpha$ calcidol daily. After obtaining consent from every patient calcium carbonate was stopped one month before enrollment in the study and all patients were kept on their usual diet during the study.

Twenty cases (group I) received calcium acetate prepared by Minapharm Pharmaceutical Co. for this research while the other 20 patient (group II) received calcium carbonate in the form of calcimat capsules each of $500 \mathrm{mg}[5 \mathrm{mMol}]$ in equimolar dose (10
$\mathrm{mMol}$ of either l.i.d.) for one month. Cross over of treatment for another one month was done. Patients were advised to take the calcium treatment during meals.

Weekly personal interviews were conducted with every patient to assess compliance to treatment and possible side effects.

Serum levels of calcium, ionized Calcium, Phosphorus, alkaline phosphates, Urea, Creatinine, Alanine transaminase (ALT), Aspartate transaminase (AST), Tolal Protcins, and Albumin were estimated before, and at the end of each month of both calcium preparations. Ionized calcium was analyzed using Electrostyl Analyzer (AVL). Beckman Autoanalyzer (Synchron Clinical System CX5) was used for other laboratory parameters.

Statistical analysis of the oblained data was done using the methods described by Armitage and Berry, 1994. The results were tabulated and statistically analyzed on an IBM personal computer using microstat package software.

\section{Results}

Five patients $(12.5 \%)$ did not tolerate calcium acetate because of nausca, vomiting and upper GIT upsel. They were excluded as non-compliant patients. Three other patients died during the course of study. The rest of the patients $(32,16$ in each group) showed good tolerance for both calcium acetate and calcium carbonatc. The results are summarized in tables 1,2 and Figures $1-3$.

Table 1. Different studied parameters before onset and after one month of calcium acctate and another month of calcium carbonate in group I

\begin{tabular}{|c|c|c|c|c|c|c|}
\hline llem & $\begin{array}{l}\text { Onset } \\
\text { (mcan } \pm \text { SD) }\end{array}$ & $\begin{array}{l}\text { Afier / month } \\
\text { (mcan } \pm \text { SD) }\end{array}$ & $\begin{array}{l}\text { After } 2 \text { momth } \\
\text { (mcan } \pm \text { SD) }\end{array}$ & $P l$ & $P 2$ & P3 \\
\hline S. calcium $(\mathrm{mg} \%)$ & 9.2410 .99 & $8.44 \pm 0.81$ & $9.5 \pm 1.45$ & $<0.001$ & $>0.05$ & $<0.01$ \\
\hline S. ionized calcium ( $\mathrm{mg} \%$ ) & $4.39 \pm 0.46$ & $4.27 \pm 0.37$ & $4.71+0.72$ & $>0.05$ & $<0.05$ & $<0.01$ \\
\hline S. phosphorus (mg\%) & $6.64 \pm 1.37$ & $6.33 \pm 2.05$ & $6.54 \pm 1.26$ & $>0.05$ & $>0.05$ & $>0.05$ \\
\hline S. alkaline phosphatase (IU/L) & $122.9-86.4$ & $134.9 \pm 114.2$ & $144.88+116.9$ & $>0.05$ & $>0.05$ & $>0.05$ \\
\hline S. urea $(\mathrm{mg} \%)$ & $165.2 \pm 18.7$ & $148.6 \pm 25.25$ & $159.56=20.98$ & $<0.05$ & $>0.0 .5$ & $>0.05$ \\
\hline S. creatinine $(\mathrm{mg} \%)$ & $12.4 \pm 4.4$ & $14.44 \pm 3.99$ & $12.93+3.57$ & $<0.05$ & $>0.05$ & $<0.05$ \\
\hline S. total protein ( $\mathrm{gm} \%)$ & $7.29 \mathrm{~J} 0.76$ & $7.29+0.69$ & $7.32 \pm 0.69$ & $>0.05$ & $>0.05$ & $>0.0 .5$ \\
\hline S. albumin ( $\mathrm{gm} \%)$ & $3.86-0.28$ & $3.73 \pm 0.29$ & $3.67 \dashv 0.36$ & $<0.05$ & $<0.05$ & $>0.05$ \\
\hline
\end{tabular}

$\mathrm{Pl}$ : Probability values in comparing the studied parameter at onset of study to its value after 1 month ol calcium acetate. P2: Probability values in comparing the studied parameter at onset of study to its value after I month of calcium carbonatc.

P3: Probability values in comparing the studied parameter after 1 month of calcium acetate to its value after 1 month of calcium carbonatc. 
Table 2. Different studied parameters before onset and after one month of calcium carbonate and another month of calcium acelate in group II

\begin{tabular}{|c|c|c|c|c|c|c|}
\hline Item & $\begin{array}{l}\text { Onset } \\
(\text { mean } \pm S D)\end{array}$ & $\begin{array}{l}\text { After I month } \\
\text { (mean } \pm S D)\end{array}$ & $\begin{array}{l}\text { After } 2 \text { month } \\
\text { (mean } \pm S D)\end{array}$ & $P I$ & $P 2$ & P3 \\
\hline S. calcium (mg\%) & $9.69 \unlhd 0.76$ & $9.46 \pm 1.33$ & $8.84 \pm 1.09$ & $>0.05$ & $<0.01$ & $<0.05$ \\
\hline S. ionized calcium ( $\mathrm{mg} \%$ ) & $4.43 \pm 0.44$ & $4.49 \pm 0.39$ & $4.25 \pm 0.5 !$ & $>0.05$ & $>0.05$ & $>0.05$ \\
\hline S. phosphorus (mg\%) & $6.68 \pm 2.13$ & $6.38 \pm 1.9$ & $5.65 \pm 1.77$ & $>0.05$ & $<0.05$ & $<0.05$ \\
\hline S. alkaline phosphatase (IU/L) & $136.8 \pm 129.6$ & $153.44+202.47$ & $168.93 \pm 240.33$ & $>0.05$ & $>0.05$ & $>0.05$ \\
\hline S. urea $(\mathrm{mg} \%)$ & $155.3 \pm 17.8$ & $149.88 \pm 20.53$ & $152.13 \pm 23.999$ & $>0.05$ & $>0.05$ & $>0.05$ \\
\hline S. creatinine $(\mathrm{mg} \%)$ & $14.1 \pm 2.68$ & $13.71 \pm 2.96$ & $12.42 \pm 1.39$ & $>0.05$ & $<0.05$ & $>0.05$ \\
\hline S. total protein (gm\%) & $6.98 \pm 0.82$ & $6.88 \pm 0.70$ & $6.956 \pm 0.71$ & $>0.05$ & $>0.05$ & $>0.05$ \\
\hline S. albumin (gm\%) & $3.78 \pm 0.43$ & $3.55 \pm 0.42$ & $3.51 \pm 0.43$ & $<0.05$ & $<0.05$ & $>0.05$ \\
\hline
\end{tabular}

P1: Probability values in comparing the studied parameter at onset of study to its value after I month of calcium carbonate.

P2: Probability values in comparing the studied parameter at onset of study to its value after 1 month of calcium acetate.

P3: Probability value in comparing the studied parameter after 1 month of calcium carbonate to its value after 1 month of calcium acetate.

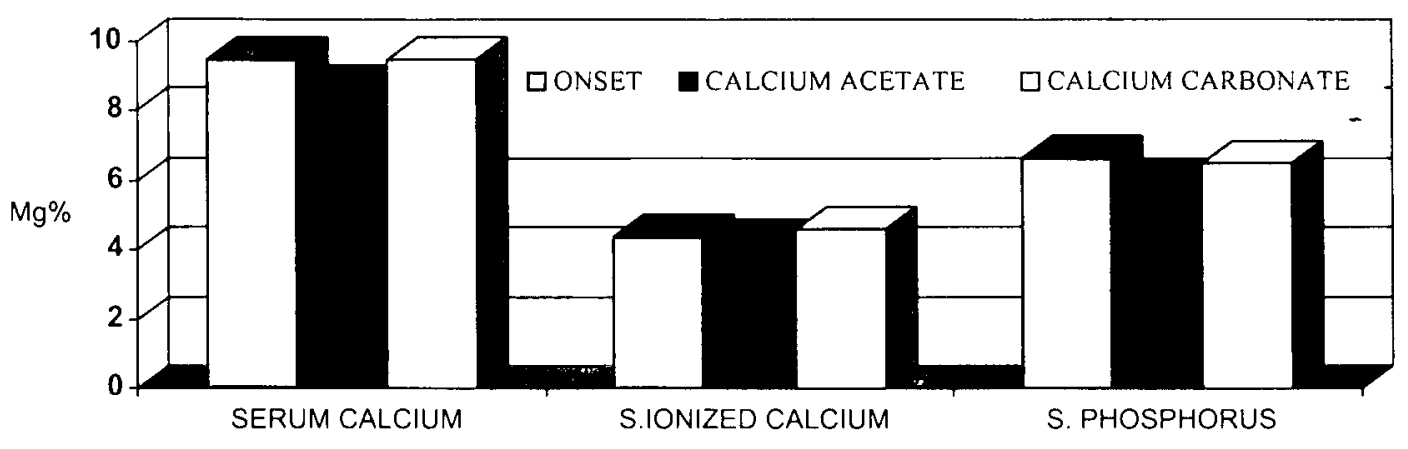

Fig. 1. Effect of calcium acelate ve calcium carbonate on S. Calcium, ionized calcium and phosphours

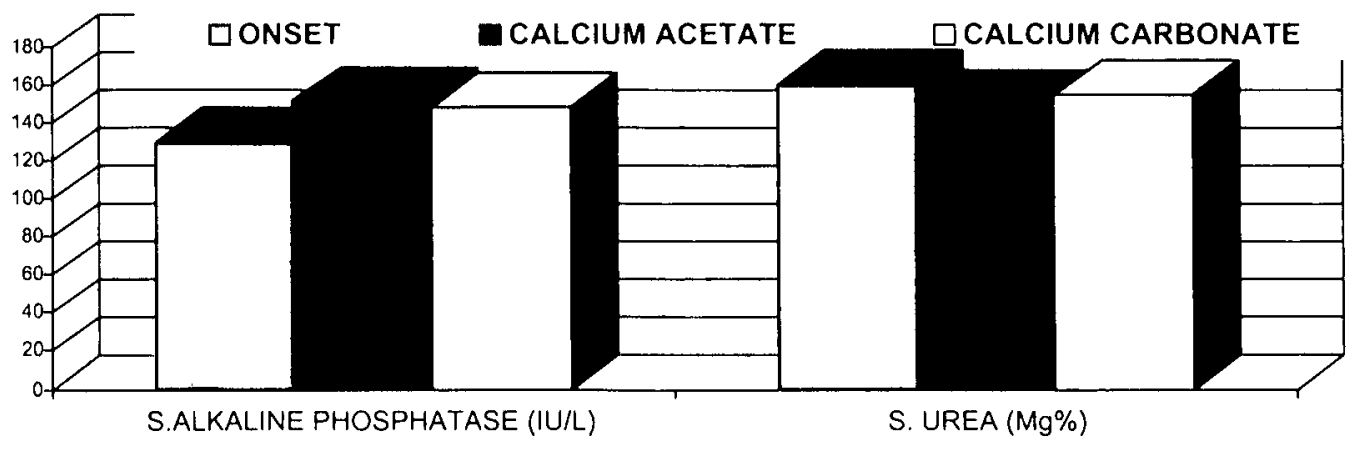

Fig. 2. Serum alkalinc phosphate and urea before, afier calcium aceate and after calcium carbonate

A significant decrease of scrum phosphorus was observed after calcium acelate when compared to values after calcium carbonate $(5.98 \pm 1.92$ vs. $6.46 \pm$ $1.59 \mathrm{mg} \%, \mathrm{p}<0.05)$. Therc is a highly significant decrase of serum total calcium after calcium acetate when compared to values after calcium carbonate
(8.63 \pm 0.96 vs. $9.47 \pm 1.37 \mathrm{mg} \%, \mathrm{p}<0.001)$ and significant decrease in serum ionized calcium after calcium acetate when compared to values after calcium carbonate $(4.25 \pm 0.44$ vs. $4.6 \pm 0.58 \mathrm{mg} \%$, $p<0.01)$. The effect of either compound on serum alkaline phosphatase was not significant. 


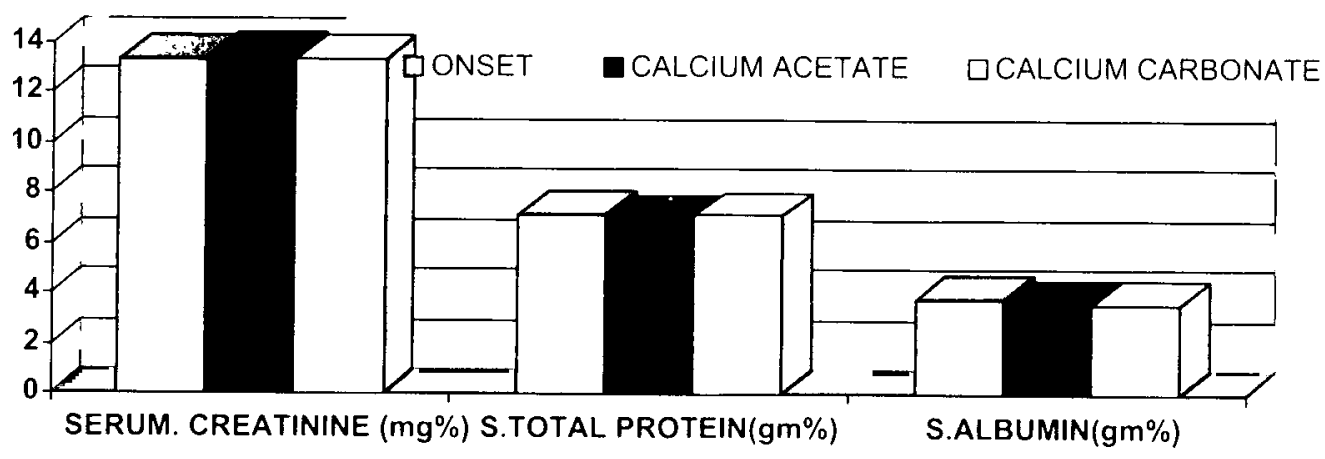

Fig. 3. Serum creatinine. total protein and albumin before and after calcium acetate and calcium carbonate

\section{Discussion}

Hyperphospatemia is one of the distressing consequences of C.R.F. It is well known that phosphorus excretion starts to deterioratc early in the course of C.R.F. and phosphate retention start at creatinine clearance less than $30 \mathrm{ml}$ leading to hyperphosphatemia $[13]$. The rising serum phosphorus lead to decrease in serum calcium, incrcase PTH secretion and suppression of vitamin D hydroxylation [10]. Retained phosphorus decreases serum calcium through its combination with this calcium either in the bone or in soft tissue |27| Increase PTH secretion in these patients is probably due to the decrease in scrum calcium, the incrcase of serum phosphorus and the decrease of aclive vit. $D_{3}$ level [27]. It is well known that lowering phosphorus level is one of the important stimulators of vitamin $D$ hydroxylation by the kidney [8]. Accordingly, the increase of phosphorus level lcads to ineffective activation of vitamin $D$ by the kidney. The skeletal manifestation of hyperphosphatemia include the following [16]:-

- Hyperdynamic bone disease due to hyperparathyroidism.

- Osteomalacia resulting from negative net calcium balance due to vit. D. dysfunction.

Accordingly, one of the important targets will be trial of normalization of serum phosphorus level in cvery uremic patient whether before or after initiation of dialysis treatment. This target may be achieved by restriction of phosphorus in the diel [15]. This approach is usually difficult, non-compliant and ineffective. Phosphorus restriction needs scvere restriction of most of the high biological value proteins including dairy products, meat, fish, eggs, meat extract, etc. On the other hand, there is increasing tendency to improve the quantity and quality of protein ingested by the uremics 10 avoid excess morbidity and mortality 141 .

In order to control the serum phosphorus in uremic patients on regular dialysis, a highly effective dialyzer with big surface arca and membrane with large bore size capable of adeciuate clcarance of phosphorus is usually needed. However, shorte treatment times with these dialyzers may offset the high clearance and thus reduce the net removal of phosphorus. In addition. a higher hacmatocrite level due 10 Erythropoictin may decrease phosphorus clearance $|7|$.

Accordingly an effeclive phosphate binder will be necded by all uremic patients either on conservative traatment or on regular hemodialysis Such a phosphate binder will allow proper nutrition of uremics without fear of hyperphosphatemia | $4 \mid$. The first phosphate binder used in these patients was aluminum hydroxide [20|. This compound has many disadvantages mainly constipation and aluminum intoxication $|26,11,25|$.

Calcium carbonate was thus introduced as an alternative phosphatc binder $|6|$. Although calcium carbonate will save the patients from aluminum intoxication, yet it causes heart burn, constipation, beside the risk of hypercalcemia. The increase of calcium absorption after calcium carbonate raiscs the serum calcium and thus deprives most patients from using active vit. D |22|. It is usually necded in these patients, not only to oplimizc calcium balance, but also to suppress the hyperactive parathyroid gland | $12 \mid$.

Another phosphate binder, the calcium citrate, is not recommended in chronic renal failure patients as it increases the absorption of aluminium traces from the gut $|24|$.

In our study, we tried a new phosphate binder, the calcium acelate, looking for its efficiency in comparison to calcium carbonate together with its effect on serum calcium whether total or ionized. In 
addition, we looked for the tolerance of patients to this new compound

The results of this study showed that calcium acetate was slightly but significantly more effective as a phosphate binder compared to calcium carbonate. This is similar to the findings of Ring et al., 1993. Meanwhile, the administration of equimolar doses of calcium acetate and carbonate showed that calcium acetate was associated with a lower level of either serum calcium or ionized calcium. The highly significant decrease of total serum calcium after calcium acetate compared to values after calcium carbonate and the significant decrease in serum ionized calcium after calcium acetate compared to values after calcium carbonate agree with the results reported by others $[21,17,5,18]$. On the other hand Almirall J, et al., 1994 reported equal effect of either compound on serum calcium. The effect of either compound on serum alkaline phosphatase was not significant as reported by Ben Hamida, 1992. This could be explained by:

1. Duration of treatment was too short to affect alkaline phosphatase level as it is not a sensitive parametcr in assessing calcium-phosphorus homeostasis in the short run.

2. The decrease in scrum total calcium and ionized calcium may ncutralize the suppressing effect of decreased serum phosphorus on parathyroid gland.

3. Patients included in this study had initially normal scrum alkaline phosphatase and thus the effect of either compound on this level will not be appreciable.

It can be concluded that calcium acelatc is a good altcrnative to calcium carbonatc as phosphate-binder with the following advantages:

It is slightly more elfective and is not associalcd with hypercalcemia. II even decreases the scrum calcium level allowing any increase in the dose.

A dialysatc containing high calcium concentration (6$7 \mathrm{mg} \%$ ) can be used without fear of hypercalcemia.

The co-administration of active vitamin $D$ will be possible allowing more effective control of scrum calcium and PTII.

However, patients tolerate this compound less than calcium carbonatc. Five patients $(12.5 \%)$ developed nausea, vomiting or GIT upset and discontinued the treatment, a finding reported by Caravaca, 1991 and Pflanz ct al., 1994.

Gencrally, long-lerm use of this compound is necessary to conlirm the speculated advantages of this compound on bone metabolism in uremic patients.

\section{Reference}

I. Almirall J, Veciana L. and Llibre J: Calcium acetate versus calcium carbonate for the control of serum phosphorus in hemodialysis patients. Am J Nephrol. 1994; 14(3): 192-196

2. Armilage $P$, and Berry $G$ : Statistical methods in medical research. Oxford Blackwell Scientific publications; $3^{\text {sd }}$ edition 1994

3. Ben Hamida F, El Esrer I., Campagnon $M$ and Morinier $P$.: Long -term cross- over comparison of calcium acetate with calcium carbonate as binder. Nephron, 1993; 63: 258-262.

4. Brenner BM and Recior FC,: Renal Osteodystrophy. In: "The Kindeny" $4^{\text {th }}$ edition. Vol. II. W.B. Saunders Company, London, Torono, Tokyo, 199 1; pp. 2068. 2073, 2088, 2089.

5. Caravaca F. Sanıos I., Cubero JJ, and Esparrago JF,: Calcium acelate versus calcium carbonate as phosphate binders Nephron. 1992; 60(4): 423-427

6. Calrkson EM, McDonald SJ, and De Wardener HE.: The effect of a high intake of calcium carbonate in norma subjects and patients with chronic renal failure. Clin Sci. 1966; 30: 425.

7. Cogan MG and Schoenfeld $P,:$ "Introduction to Dialysis". $2^{\text {nd }}$ edition Churchill Livingstone. New York. London, Tokyo, 1991; pp. 271-275.

8. Day $\mathrm{HG}$ and McCollum E.: Mineral metabolism growth and symptomatology of rats on a diet extremely deficient in phosphorus. J.Biol. Chem.. 1939; 130:269.

9. Felsenfeld AJ, Gutrnan RA, Llach F, and Harrelson JM, Osteomalacia in chronic renal failure: A syndrome previously reported only with maintenance dialysis. Am J Nephrol; 1982; 2: 147-154.

10. Fournier A, Arnaud CP, Johnson WJ, el al,, Etiology of hyperparathyroidism and bone disease during chronic hemodialysis. 11. Factors affecting serum immune reactive parathyroid hormone. J. Clin. Invest, 1971; 50:599

11. Fournier A, Moriniere P, Ben Hamida F, el Esjer N, Shenovda M. Ghazali A, Bouzernidj M, Achard JM. Wcsteel PF: Use of alkaline calcium salts as phosphate binder in uremic patients. Kidney Int 1992; [Suppl $\mathrm{Ocl} ; 38]: 550-\mathrm{S} 6 \mathrm{I}$

12. Fournier A, Sebert JL and Gevoet B, Current status of the management of renal osteodystrophy. Proc.EDTA. 15:547.

13. Goldman R and Bassett SH,1954: Phosphorus excretion in renal failure. J.Clin.Invesi, 1978; 33:1623.

14. Kopplc JD and Coburn JW.: Metabolic studies of low protein diets in uremia. II.Calcium, phosphorus and magnesium. Medicine: 1973: 52: 597.

15. Liach $F$ and Massry $S G$,: On the mechanism of the prevention of $2^{7}$ hyperparalhyroididin in moderate renal insufficiency. J Clin Endocrin Melab, 1985: 61:601.

16. Massry $S G$, Divalent ion metabolism and renal osteodystrophy. In: Masry SG and Glassock RJ(Eds) "Texibook of ncphrology" $2^{\text {thd }}$ edition. Vol. I. William and Wilkins. Balimore, London. 1982; p 104

17. Morinierc PIl. Roussel A. Tahiri Y, el al.,: Substitution of aluminum hydroxide by high doses of calcium carbonate in patients on hemodialysis: Disappearance of hyperaluminemia and equal control of hyerparathyroidism. Proc. Eur. Dial. Transplant. Assoc; 1983; 19: 784-787.

18. Pllanz S, Henderson IS, McElduff $N$, and Jones $M C$, Calcium acetate versus calcium carbonatc as phosphatebinding agents in chronic haemodialysis. Nephrol Dial Transplant, 1994; 9(8):1121-1124.

19. Ring T. Nielsen C, Andersen SP. Behrens JK. Sodemann B, and Kornerup $\mathrm{HJ}_{\text {: }}$ Calcium acetate versus calcium carbonatc as phosphorus binders in patients on chronic hacmodialysis: a controlled study. Nephrol Dial Transplant 1993:8(4):341-346.

20. Ruiherford E, Mercado A, Hruska K, et al..: An evaluation of a new and effective phosphorous binding agent. Trans. Am. Soc. Antif. Intern. Organs, 1973: 19: 446.

21. Sheikh MS, Maquire JA, Emmeu M, et al.,: Reduction of dielary phosphorus absorplion by phosphorus binders: A 
theortical in vitro and in vivo study. J Clin Invest. 1989;66:83.

22. Shiller LR, Sania Ana CA. Sheikh MS. et al.: Effect of the time of administration of calcium acelate on phosphorus binding. $N$. Engl. J. Med., 1989; 320:1110.

23. Slatopolsky E.: The interaction of parathyroid hormone and aluminium in renal osteodystrophy. Kidncy Inı. 1987;31:842.

24. Van den Bergh JP. Kaufmann BG, van Riet GJ. Bottger WM. Verstappen VM.: Comparison of threc formulations of calcium acetate tablets to evaluate tolerance and control of hyperphosphatemia in patients with chronic renal failure. Nephron, 1994: 68(4):505-506
25. Vogelsang $U$.: Aluminum poisoning in dialysis patientsdiagnosis and therapy. Schwei, Runduch Med Prax Jun, 14. 1994: 83(24):738-756.

26. Ward MK. Feest TG. Ellis HA. et al..: Osteomalacic dialyss osteodystrophy: Evidence for a water- bone actiological agent, probably aluminium. Lancet. 1978; 1:8211.

27. Wilson L. Felsenfeild. A. Dresner MK, and Liach F. Alered divalent ion metabolism in carly renal failure. Role of $1.25(\mathrm{OH})_{2} \mathrm{D}_{3}$. Kid Int. 1985: 27: 565 . 